\title{
The pharmacological treatment of epilepsy: recent advances and future perspectives
}

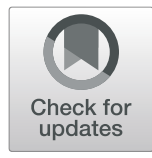

Emilio Perucca ${ }^{1,2}$ (D)

\begin{abstract}
The pharmacological armamentarium against epilepsy has expanded considerably over the last three decades, and currently includes over 30 different antiseizure medications. Despite this large armamentarium, about one third of people with epilepsy fail to achieve sustained seizure freedom with currently available medications. This sobering fact, however, is mitigated by evidence that clinical outcomes for many people with epilepsy have improved over the years. In particular, physicians now have unprecedented opportunities to tailor treatment choices to the characteristics of the individual, in order to maximize efficacy and tolerability. The present article discusses advances in the drug treatment of epilepsy in the last 5 years, focusing in particular on comparative effectiveness trials of second-generation drugs, the introduction of new pharmaceutical formulations for emergency use, and the results achieved with the newest medications. The article also includes a discussion of potential future developments, including those derived from advances in information technology, the development of novel precision treatments, the introduction of disease modifying agents, and the discovery of biomarkers to facilitate conduction of clinical trials as well as routine clinical management.
\end{abstract}

Keywords: Epilepsy, Seizures, Drug therapy, Antiepileptic drugs, Antiseizure medications, Advances, Review

\section{Background}

The modern treatment of epilepsy started with the introduction of phenobarbital in 1912. The advent of phenytoin in the late thirties marked another milestone, because it was made possible by the introduction of animal models of antiseizure activity [1]. Similar models also played a key role in the subsequent development of many other antiseizure medications (ASMs). Today, the pharmacological armamentarium against epilepsy includes more than 30 drugs (Table 1). These drugs differ in their pharmacokinetics, efficacy, and adverse effect profile, thereby offering unprecedented opportunities to tailor treatment choices to individual needs [2]. Some of

\footnotetext{
Correspondence: perucca@unipv.it

This article is dedicated to the memory of Professor Alan Richens (1938-2021), my mentor and dear friend, in recognition of his outstanding contribution to advancing the pharmacological treatment of epilepsy.

${ }^{1}$ Department of Internal Medicine and Therapeutics, Division of Clinical and Experimental Pharmacology, University of Pavia, Via Ferrata 9, 27100 Pavia, Italy

${ }^{2}$ Department of Neuroscience, Central Clinical School, Monash University, Melbourne, Victoria 3004, Australia
}

the ASMs introduced after 1985, usually referred to as second-generation drugs, have some safety advantages over older generation agents, but have not increased substantially the proportion of patients who achieve complete freedom from seizures [3]. For many of these patients, the feasibility of epilepsy surgery, or alternative therapies, should be given early consideration $[4,5]$.

Despite the fact that pharmacoresistance has been little affected by the introduction of newer medications, the drug treatment of epilepsy has made major advances in the last 50 years. In particular, we learnt how to individualize drug selection based on specific patient characteristics such as age, gender, epilepsy syndrome, seizure type, comorbidities, comedications, and other factors affecting clinical response [6]. We also learnt how to optimize response by careful titration and adjustment of dosage, and use of serum drug levels whenever indicated [7]. We made major progress in understanding drug interactions, and recognizing the relative merits and indications of monotherapy and polytherapy $[8,9]$. Likewise, we improved our knowledge of the natural

(c) The Author(s). 2021 Open Access This article is licensed under a Creative Commons Attribution 4.0 International License, which permits use, sharing, adaptation, distribution and reproduction in any medium or format, as long as you give appropriate credit to the original author(s) and the source, provide a link to the Creative Commons licence, and indicate if changes were made. The images or other third party material in this article are included in the article's Creative Commons licence, unless indicated otherwise in a credit line to the material. If material is not included in the article's Creative Commons licence and your intended use is not permitted by statutory regulation or exceeds the permitted use, you will need to obtain permission directly from the copyright holder. To view a copy of this licence, visit http://creativecommons.org/licenses/by/4.0/. 
Table 1 Years of introduction in the market of currently available antiseizure medications. For all drugs, year of introduction refers to either Europe or the United States of America. The table does not include a number of drugs approved before 1970, but rarely used today

\begin{tabular}{|c|c|c|c|c|}
\hline $1900-1950$ & 1951-1985 & $1986-2000$ & 2001-2015 & 2015-2021 \\
\hline $\begin{array}{l}\text { Phenobarbital } \\
\text { Phenytoin }\end{array}$ & $\begin{array}{l}\text { Carbamazepine } \\
\text { Clobazam } \\
\text { Clonazepam } \\
\text { Diazepam } \\
\text { Ethosuximide } \\
\text { Midazolam } \\
\text { Primidone } \\
\text { Valproic acid }\end{array}$ & $\begin{array}{l}\text { Felbamate } \\
\text { Fosphenytoin } \\
\text { Gabapentin } \\
\text { Lamotrigine } \\
\text { Levetiracetam } \\
\text { Lorazepam } \\
\text { Oxcarbazepine } \\
\text { Tiagabine } \\
\text { Topiramate } \\
\text { Vigabatrin } \\
\text { Zonisamide }\end{array}$ & $\begin{array}{l}\text { Eslicarbazepine acetate } \\
\text { Lacosamide } \\
\text { Perampanel } \\
\text { Pregabalin } \\
\text { Rufinamide } \\
\text { Stiripentol }\end{array}$ & $\begin{array}{l}\text { Brivaracetam } \\
\text { Cannabidiol } \\
\text { Cenobamate } \\
\text { Everolimus } \\
\text { Fenfluramine }\end{array}$ \\
\hline
\end{tabular}

history of epilepsy syndromes, and characterized prognostic factors for seizure recurrence for patients in whom discontinuation of ASMs can be considered after an adequate period of freedom from seizures [10].

The purpose of the present article is to provide a concise overview of some advances in research on the drug treatment of epilepsy made in the last 5 years, and to discuss currently unmet needs as well as developments which are likely to occur in the foreseeable future.

\section{Advances in characterizing the comparative effectiveness and safety of ASMs}

A number of recent clinical trials and observational studies have provided valuable information which can assist physicians in making rational treatment selections. As a follow-up to the initial Standard and New Antiepileptic Drugs (SANAD) trials, which found lamotrigine to be superior to carbamazepine, oxcarbazepine, topiramate and gabapentin in time to treatment failure in patients with mostly focal epilepsy [11], and valproate to be superior to lamotrigine and topiramate in patients with mostly generalized and unclassified epilepsy [12], two more recent SANAD trials have been completed. In the first of these trials, 990 adults and children with newly diagnosed focal epilepsy were randomized to receive lamotrigine, levetiracetam or zonisamide, and followed-up for 2 years [13]. In the per-protocol analysis, lamotrigine was associated with a better 12-month remission from seizures compared with both levetiracetam and zonisamide. In the second SANAD-II trial, which used a similar protocol and enrolled 520 newly diagnosed adults and children, valproate was found to be more effective than levetiracetam in controlling seizures in a pooled cohort of patients with generalized or unclassified epilepsy [14]. These trials used a pragmatic design mimicking routine clinical practice, even though the possibility of assessment bias due to the open-label, unblinded design cannot be excluded. When considered together with other available lines of evidence, these findings confirm that lamotrigine should be regarded as one of the treatments of first choice for patients with focal seizures. Lamotrigine offers the advantage of being efficacious, generally devoid of adverse effects on mood and cognitive function, and with a low potential to cause adverse drug interactions, even though lamotrigine metabolisn can be affected by a variety of concurrently administered drugs [6]. One drawback of lamotrigine is the need for gradual titration in order to minimize the risk of serious skin rashes, and therefore it may not be the most appropriate drug for use in patients with frequent severe seizures requiring a prompt onset of antiseizure activity.

The findings from the SANAD studies that valproate is superior to lamotrigine, topiramate and levetiracetam in the treatment of patients with generalized epilepsy are consistent with other lines of evidence. In particular, a recent study from Denmark found that failure to achieve seizure freedom with valproate was the single most important predictor of pharmacoresistance in a cohort of 137 adults with idiopathic (genetic) generalized epilepsy [15]. The superior efficacy of valproate in controlling seizures associated with generalized epilepsy, however, creates a dilemma in the treatment of females of childbearing potential. In fact, valproate is regarded by the European Medicine Agency as contraindicated for use as first-line treatment in these women (unless the conditions of a rigorous pregnancy prevention programme are fulfilled), due to the higher risk of inducing teratogenic effects as well as impaired postnatal cognitive development in the offspring [16, 17].

With respect to teratogenic potential of ASMs, prospective pregnancy registries have contributed greatly to characterize risks associated with individual medications. A particularly important advance was the 2018 publication of data from the international EURAP registry [18]. This study, based on analysis of 7355 prospective pregnancies exposed to 8 different ASM monotherapies provides risk estimates non only for specific ASMs, but also for different doses of the most commonly used drugs. Overall, the lowest prevalence of major congenital malformations (MCMs) in the offspring was associated with exposure to levetiracetam (2.8\% prevalence), lamotrigine (2.9\%) and oxcarbazepine (3.0\%). Prevalence estimates were intermediate for topiramate (3.9\%), 
carbamazepine (5.5\%), phenytoin (6.4\%) and phenobarbital (6.5\%), and highest for valproate (10.3\%). An increased risk with increasing dose was identified for lamotrigine and carbamazepine, and was most prominent for phenobarbital and valproate. In particular, the prevalence of MCMs (with 95\% confidence intervals) associated with phenobarbital exposure was $2.7 \%(0.3-9.5 \%)$ at doses $\leq 80 \mathrm{mg} /$ day, $6.2 \%$ (3.0$11.1 \%)$ at doses $>80$ to $\leq 130 \mathrm{mg} /$ day and $11.7 \%(4.8-22.6 \%)$ at doses $>130 \mathrm{mg} /$ day. For valproate, the prevalence of MCMs was $6.3 \%(4.5-8.6 \%)$ at doses $\leq 650 \mathrm{mg} /$ day, $11.3 \%$ $(9.0-13.9 \%)$ at doses $>650$ to $\leq 1450 \mathrm{mg} /$ day and $25.2 \%$ $(17.6-34.2 \%)$ at doses $>1450 \mathrm{mg} /$ day. These findings are important because they alert physicians about the need to consider teratogenic risks not only in relation to type of ASM prescribed, but also in relation to dose. A subsequent EURAP investigation documented a clear-cut decrease in the prevalence of MCMs over the period from 2000 to 2013 [19]. Specifically, there was a $27 \%$ decrease in prevalence of MCMs between pregnancies enrolled in the period 2010 2013 compared with those enrolled in the period 2000-2005 (Fig. 1). Further analysis of these data provided a strong indication that the improvement in pregnancy outcomes over time was related to changes in ASM prescription patterns, including a major decline in the proportion of pregnancies exposed to valproate. In fact, a reduction in teratogenic risk is one of the important advances associated with the introduction of second-generation ASMs [3].

\section{Introduction of novel ASMs}

During the last 5 years, five novel ASMs (brivaracetam, cannabidiol, cenobamate, everolimus and fenfluramine) have been introduced into the market. Key features of each of these medications are summarized in Table 2 . The history of these drugs is illustrative of different strategies being used in developing novel ASMs.

The development of brivaracetam followed a paradigm which has been in place for a very long time, i.e. the structural modification of an already existing medication with the aim of improving its pharmacological profile. Examples of other ASMs developed with this strategy include methylphenobarbital and primidone (both structurally related to phenobarbital), the phenytoin derivative fosphenytoin, and oxcarbazepine and eslicarbazepine acetate, which represent successive modifications of the carbamazepine structure. In fact, levetiracetam itself was originally developed with the aim of improving the pharmacological profile of piracetam, and its antiseizure activity was discovered by chance. Brivaracetam was selected for development after extensive preclinical screening of a large numbers of levetiracetam derivatives. Compared with levetiracetam, brivaracetam has higher affinity for the synaptic vesicle 2A (SV2A), and a similar pharmacological profile [20]. Brivaracetam has been found to be superior to placebo in adjunctive-therapy trials in focal epilepsy, but its activity profile in other seizure types has not yet been defined in well designed controlled trials. One limitation of brivaracetam is its lack of efficacy when added-on to levetiracetam, presumably due to competition between the two drugs for the SV2A binding site. The still unanswered question about brivaracetam is whether, and to what extent, its efficacy and

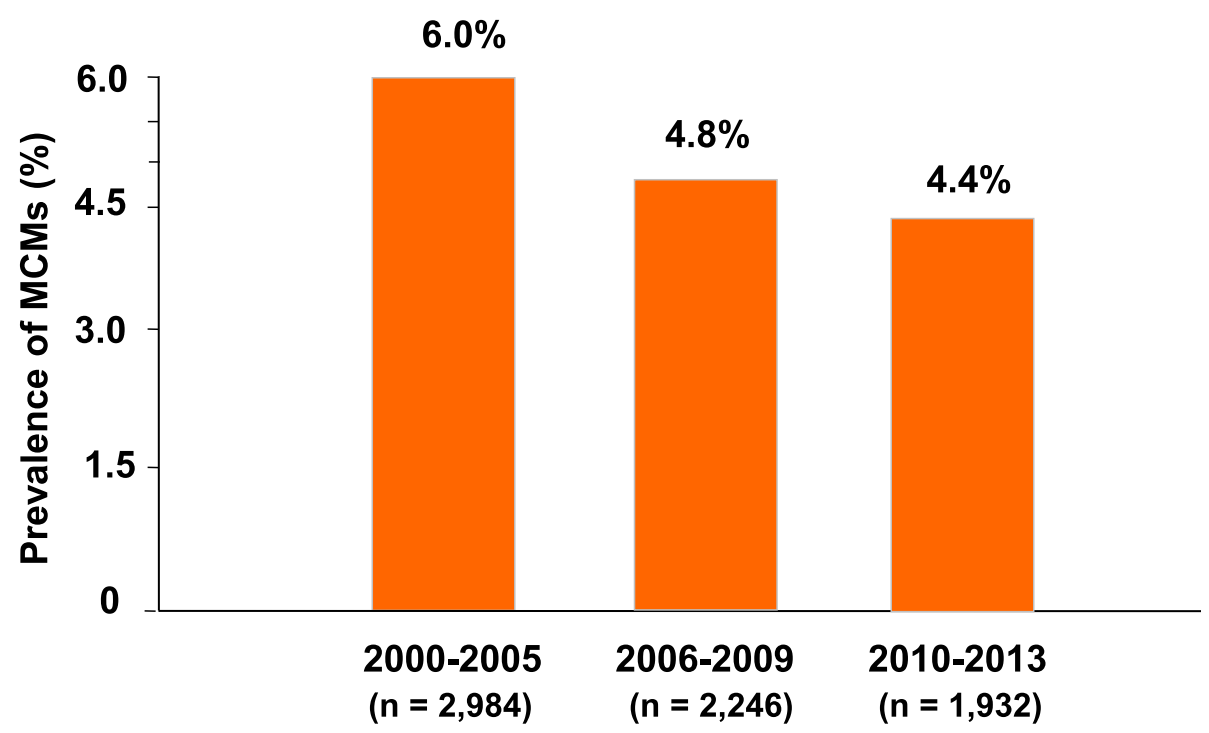

Fig. 1 Prevalence of major congenital malformations (MCMs) following prenatal exposure to monotherapy with antiseizure medications (ASMs) among cases enrolled in the EURAP international registry during three different periods. Number of exposures during each period (listed in brackets) refer to the eight most common monotherapies, which accounted for 96.7 to $98.1 \%$ of all monotherapy exposures. Based on data from Tomson et al [19]. 
Table 2 Summary of the pharmacological and clinical profile of antiseizure medications (ASMs) introduced in the market after 2015

\begin{tabular}{|c|c|c|c|c|c|}
\hline & Brivaracetam & Cannabidiol & Cenobamate & Everolimus & Fenfluramine \\
\hline $\begin{array}{l}\text { Chemical } \\
\text { structure }\end{array}$ & Levetiracetam derivative & Cannabinoid & Carbamate derivative & Rapamycin derivative & Amphetamine derivative \\
\hline $\begin{array}{l}\text { Approved } \\
\text { epilepsy } \\
\text { indications } \\
\text { (United } \\
\text { States) }\end{array}$ & $\begin{array}{l}\text { Treatment of focal } \\
\text { seizures in patients aged } \\
1 \text { month and older }\end{array}$ & $\begin{array}{l}\text { Treatment of seizures } \\
\text { associated with LGS, DS } \\
\text { or TSC in patients } 1 \text { year } \\
\text { of age and older }\end{array}$ & $\begin{array}{l}\text { Treatment of focal } \\
\text { seizures in adults }\end{array}$ & $\begin{array}{l}\text { Add-on treatment of } \\
\text { focal seizures } \\
\text { associated with TSC in } \\
\text { patients aged } 2 \text { years } \\
\text { and older }\end{array}$ & $\begin{array}{l}\text { Treatment of seizures } \\
\text { associated with DS in } \\
\text { patients } 2 \text { years of age } \\
\text { and older. }\end{array}$ \\
\hline $\begin{array}{l}\text { Main } \\
\text { mechanisms } \\
\text { of action }\end{array}$ & SV2A modulator & $\begin{array}{l}\text { Several, including } \\
\text { GPR55 antagonism, } \\
\text { desensitization of } \\
\text { TRPV1channels, } \\
\text { enhanced adenosine- } \\
\text { mediated signaling, and } \\
\text { GABAergic effects. }\end{array}$ & $\begin{array}{l}\text { Blockade of persistent } \\
\text { sodium currents and } \\
\text { increase of phasic and } \\
\text { tonic GABA inhibition. }\end{array}$ & mTOR inhibition & $\begin{array}{l}\text { Several, including indirect } \\
\text { stimulation of } 5-\mathrm{HT}_{2 \mathrm{C}} \text { and } \\
5-\mathrm{HT}_{1 \mathrm{D}} \text { receptors as well } \\
\text { as interactions with } \sigma 1- \\
\text { receptors }\end{array}$ \\
\hline $\begin{array}{l}\text { Oral } \\
\text { bioavailability }\end{array}$ & Complete (100\%) & $\begin{array}{l}\text { About } 6 \% \text { in the fasting } \\
\text { state. About } 25 \% \text { when } \\
\text { taken with a high-fat } \\
\text { meal }\end{array}$ & About 90\% & Variable & About $80 \%$ \\
\hline $\begin{array}{l}\text { Main route } \\
\text { of } \\
\text { elimination }\end{array}$ & $\begin{array}{l}\text { CYP2C19-mediated } \\
\text { hydroxylation and } \\
\text { hydrolysis }\end{array}$ & $\begin{array}{l}\text { CYP2C19 and CYP3A4- } \\
\text { mediated oxidation, and } \\
\text { other metabolic } \\
\text { pathways }\end{array}$ & $\begin{array}{l}\text { UGT2B7- and UGT2B4- } \\
\text { mediated glucuronida- } \\
\text { tion and CYP-mediated } \\
\text { oxidation }\end{array}$ & $\begin{array}{l}\text { CYP3A4-mediated } \\
\text { metabolism }\end{array}$ & $\begin{array}{l}\text { CYP-mediated } \\
\text { metabolism, involving } \\
\text { conversion to the active } \\
\text { metabolite } \\
\text { norfenfluramine }\end{array}$ \\
\hline Half-life & About $9 \mathrm{~h}$ & $\begin{array}{l}\text { About } 15 \mathrm{~h} \text { after a single } \\
\text { dose, and about } 60 \mathrm{~h} \\
\text { after multiple dosing }\end{array}$ & About 50-60 h & About $30 \mathrm{~h}$ & $\begin{array}{l}\text { Fenfluramine }=\text { about } 20 \\
\text { h. Norfenfluramine }= \\
\text { about } 24 \text { to } 48 \mathrm{~h}\end{array}$ \\
\hline $\begin{array}{l}\text { Most } \\
\text { common } \\
\text { adverse } \\
\text { effects }\end{array}$ & $\begin{array}{l}\text { Sommnolence, fatigue, } \\
\text { dizziness, coordination } \\
\text { disturbances, mood and } \\
\text { behavioural disturbances }\end{array}$ & $\begin{array}{l}\text { Somnolence, anorexia, } \\
\text { diarrhea, fatigue, sleep } \\
\text { disorders, behavioral } \\
\text { disturbances }\end{array}$ & $\begin{array}{l}\text { Dizziness, fatigue, } \\
\text { somnolence, ataxia, } \\
\text { dysarthria, visual } \\
\text { disturbances, } \\
\text { gastrointestinal } \\
\text { disturbances }\end{array}$ & $\begin{array}{l}\text { Stomatitis, pyrexia, } \\
\text { pneumonia, diarrhea, } \\
\text { hypercholesterolemia }\end{array}$ & $\begin{array}{l}\text { Anorexia, decreased } \\
\text { weight, diarrhea, } \\
\text { constipation, } \\
\text { somnolence, fatigue, } \\
\text { coordination } \\
\text { disturbances, behavioral } \\
\text { disturbances }\end{array}$ \\
\hline $\begin{array}{l}\text { Other } \\
\text { adverse } \\
\text { effects of } \\
\text { potential } \\
\text { concern }\end{array}$ & Hypersensitivity reactions & $\begin{array}{l}\text { Hypersensitivity reactions, } \\
\text { increased liver enzymes, } \\
\text { pneumonia }\end{array}$ & Hypersensitivity reactions & $\begin{array}{l}\text { Hypersensitivity } \\
\text { reactions, infections, } \\
\text { renal failure, } \\
\text { myelosuppression }\end{array}$ & $\begin{array}{l}\text { Cardiac valvulopathy, } \\
\text { pulmonary hypertension, } \\
\text { serotonin syndrome }\end{array}$ \\
\hline $\begin{array}{l}\text { Main drug } \\
\text { interactions }\end{array}$ & $\begin{array}{l}\text { Serum brivaracetam levels } \\
\text { can be increased by } \\
\text { cannabidiol, and } \\
\text { moderately reduced by } \\
\text { enzyme inducing ASMs. } \\
\text { Brivaracetam increases } \\
\text { serum levels of carbama- } \\
\text { zepine-10,11-epoxide }\end{array}$ & $\begin{array}{l}\text { Cannabidiol inhibits the } \\
\text { metabolism of several } \\
\text { drugs. In particular, it } \\
\text { increases markedly the } \\
\text { serum levels of } \\
\text { norclobazam, the active } \\
\text { metabolite of clobazam }\end{array}$ & $\begin{array}{l}\text { Serum cenobamate } \\
\text { levels are decreased by } \\
\text { phenytoin. Cenobamate } \\
\text { increases serum } \\
\text { phenytoin levels, and can } \\
\text { modify the serum levels } \\
\text { of several other drugs }\end{array}$ & $\begin{array}{l}\text { Serum everolimus } \\
\text { levels can be increased } \\
\text { by inhibitors of P-gp } \\
\text { and by CYP3A4 inhibi- } \\
\text { tors, and decreased by } \\
\text { inducers of P-gp / } \\
\text { CYP3A4 }\end{array}$ & $\begin{array}{l}\text { Serum fenfluramine levels } \\
\text { are increased by the } \\
\text { combination of } \\
\text { stiripentol with clobazam. } \\
\text { Use together with other } \\
\text { serotoninergic drugs may } \\
\text { involve a risk of } \\
\text { precipitating a serotonin } \\
\text { syndrome }\end{array}$ \\
\hline
\end{tabular}

Abbreviations: CYP cytochrome P450; DS Dravet syndrome; GABA gamma-aminobutyric acid, GPR55 G protein-coupled receptor 55, LGS Lennox-Gastaut syndrome; mTOR mechanistic target of rapamycin; P-gp P-glycoprotein, TRPV1 transient receptor potential vanilloid type 1, TSC tuberous sclerosis complex, UGT uridine 5'-diphospho-glucuronosyltransferase

tolerability profile differs from that of levetiracetam. It has been suggested that brivaracetam is less likely to cause irritability and other behavioral disturbances compared with levetiracetam [20]. However, evidence on this remains inconclusive, because to date there have been no randomized head-to-head trials comparing these two drugs [21].
Another ASM recently approved for the treatment of focal seizures is cenobamate, a carbamate derivative which is also structurally related to previously developed drugs [22]. During clinical development, three confirmed cases of DRESS (Drug Reaction with Eosinophilia and Systemic Symptoms), including one fatality, were reported when cenobamate was titrated rapidly (weekly 
or faster titration). Consequently, a revised dosing scheme involving initiation at a small dose and slow titration at 2-week intervals has been implemented. In a safety study, no cases of DRESS were reported when 1339 patients were titrated using the slow titration scheme, and the drug has since been approved in the U.S. and Europe [23]. In the pivotal adjunctive-therapy randomized trial in patients with refractory focal seizures that led to regulatory approval, the most remarkable finding was the relatively high proportion of patients who achieved seizure freedom (21\% in the 400 $\mathrm{mg} /$ day cenobamate group versus $1 \%$ in the placebo group) [24]. This contrasts with seizure freedom rates ranging from 0 to $6.5 \%$ in comparable trials with other second-generation ASMs [25]. Comparisons of outcome data across trials, however, should be interpreted cautiously, because of differences in clinical settings and characteristics of the patients. Moreover, seizure freedom data in randomized clinical trials refer to limited assessment periods (typically, a 12-week maintenance period) and can be inflated by the last-observationcarried-forward (LOCF) analysis, whereby patients who did not experience seizures but exited the trial prematurely are still counted as seizure-free in the final analysis. In the pivotal cenobamate trial, the proportion of randomized patients who were seizure-free during the entire 12-week maintenance period and did not exit the trial prematurely was $14 \%$, which is still a relatively high proportion [24].

All three remaining ASMs introduced in the last 5 years share a common feature, i.e. they were approved for orphan indications. Specifically, cannabidiol was approved for the treatment of seizures associated with Dravet syndrome, Lennox-Gastaut syndrome and tuberous sclerosis complex, fenfluramine was approved for the treatment of seizures associated with Dravet syndrome, and everolimus was approved for the add-on treatment of focal seizures in patients with tuberous sclerosis complex (Table 2). Introduction of ASMs for orphan indications is a novel development, made possible by increased awareness of the unmet needs associated with many rare epilepsies and by regulatory incentives to develop drugs for these indications, particularly for children. In fact, only 2 of the 25 ASMs developed prior to 2015 were developed for orphan indications, compared with 3 out of 5 ASMs developed in the last 5 years.

Cannabidiol is one of the many active principles contained in the Cannabis plant, which has been used as an herbal remedy in China as early as $2000 \mathrm{BC}$. Unlike tetrahydrocannabidol (THC), cannabidiol lacks unwarranted psychoactive effects. Its antiseizure efficacy in its approved indications has been demonstrated in several adjunctive-therapy randomized placebo-controlled trials
[26]. In these trials, many patients received concomitant treatment with clobazam, and the improvement in seizure control observed after adding cannabidiol could be ascribed at least in part to a drug interaction. In fact, cannabidiol is a powerful inhibitor of cytochrome CYP2C19 and by this mechanism increases more than three-fold the serum concentration of norclobazam, the active metabolite of clobazam. There is, however, also evidence that cannabidiol retains independent antiseizure activity, unrelated to its interaction with clobazam [27].

Another ASM recently introduced for the treatment of seizures associated with Dravet syndrome is fenfluramine, which was first marketed in the sixties and widely used in Europe and the U.S. for over 30 years as an appetite suppressant, either as racemic fenfluramine or as its d-enantiomer dexfenfluramine. In 1997, fenfluramine and dexfenfluramine were withdrawn from the market following the discovery of their association with cardiac valvulopathy and pulmonary hypertension. Prior to its withdrawal from the market, however, fenfluramine had been found to improve seizure control in a small cohort of patients with Dravet syndrome, who were allowed to continue treatment with the drug [28]. These observations led to recent conduction of randomized placebocontrolled adjunctive therapy trials, which demonstrated a robust seizure-suppressing effect in patients with Dravet syndrome, and subsequent regulatory approval for this indication both in Europe and the United States [29]. Recent data suggest that fenfluramine may also be useful for the treatment of seizures associated with Lennox-Gastaut syndrome [30]. To date, no evidence of cardiovascular toxicity has been found in patients with epilepsy treated with fenfluramine, possibly because the doses used for seizure protection are generally lower than those used originally for appetite suppression. Yet, there are still many unanswered questions concerning fenfluramine, including the serum levels of parent drug and its active de-ethylated metabolite norfenfluramine required for seizure suppression in children in comparison with those known to be associated with cardiovascular toxicity in adults [29]. The potential efficacy and safety advantages of developing individual enantiomers of fenfluramine and norfenfluramine should also be considered [29].

The last medication discussion in this section, everolimus, is an inhibitor of mTOR (mammalian Target Of Rapamycin). Its use in the treatment of focal seizures associated with tuberous sclerosis complex (TSC) has been prompted by evidence linking the pathogenesis of TSC to mTOR overactivation [31]. Accordingly, everolimus is an example of a novel strategy in drug development, i.e. a precision treatment targeting the etiology of the disease. Everolimus has been found to be effective in 
reducing tumor growth as well as drug-resistant seizures in TSC patients. Up to $40 \%$ of TSC patients show a significant improvement in seizure control when given adjunctive treatment with everolimus. In the pivotal trial that led to its regulatory approval for use as ASM, seizure frequency decreased progressively over time during treatment, suggesting a possible disease modifying effect [32]. However, a clinically relevant antiepileptogenic or disease-modifying effect has not yet been clearly demonstrated. The age at which treatment is initiated may be important for the final outcome, but controlled trials in children below 2 years of age have not yet been completed [31].

Cannabidiol, fenfluramine and everolimus are also examples of drugs approved initially for other indications. In fact, cannabidiol was first marketed in a fixed combination product with THC as a nasal spray for the treatment of spasticity associated with multiple sclerosis, fenfluramine was used initially as an appetite suppressant, and everolimus was first approved for the treatment of advanced kidney cancer, subependymal giant cell astrocytoma (SEGA) associated with TSC, pancreatic neuroendocrine tumors, and other tumors. The repurposing for use in epilepsy of drugs initially approved for other indications is one of the options being pursued in the effort to develop precision treatments (see below).

\section{Introduction of novel formulations}

Advances in epilepsy treatment can be achieved not only by developing novel drugs, but also by improving the pharmaceutical formulation of already available medications. One area where particularly significant advances have been made in the last 5 years is the development of novel formulations of ASMs for the treatment of seizure clusters and acute repetitive seizures in the out-of-hospital setting [33]. Until 2018, the only FDA-approved rescue ASM for out-of-hospital use was diazepam rectal gel. In 2019, the FDA approved two additional products for this indication, namely intranasal midazolam [34] and intranasal diazepam [35]. Use of these medications is associated with a rapid onset of antiseizure effect, thereby stopping seizures before they progress to established status epilepticus. The intranasal route is generally well accepted by patients and caregivers, as it avoids the social embarrassment associated with use of the rectal route.

Alternative non-rectal rescue formulations of benzodiazepines for out-of-hospital use have been available in other countries for a number of years. In particular, a rapidly absorbed buccal formulation of midazolam has been available in Europe since 2011 [36]. Innovative formulations of ASMs under development as potential rescue therapy for emergency use include a diazepam buccal film, and an inhaled formulation of alprazolam [33]. Oral formulations can also be used at times as a rescue treatment, but they can be associated with drawbacks in this setting, such as slower or suboptimal absorption, need for patient cooperation (which is not always feasible) and risk of aspiration [36].

\section{Future perspectives}

Extensive research is ongoing in many areas, and important advances leading to improved epilepsy outcomes are likely to occur in a not too distant future. A few relevant examples will be discussed below.

\section{Increased application of technological tools to epilepsy management}

In recent years, information technology (IT)-based applications have been increasingly utilized in epilepsy management, as shown by the widespread use of smartphones to record seizures in the out-hospital setting, and the expanding opportunities offered by Internetbased services in areas such as distant education and telemedicine [37]. Smartphone applications (apps) are also being increasingly used to assist people with epilepsy to manage and cope with their disease. Most of these apps focus on issues such as treatment management, medication adherence, health care communication, and seizure tracking [38]. Other apps are aimed at assisting healthcare professionals (HCPs), on example being tools to improve epilepsy diagnosis in nonspecialist settings $[39,40]$. We recently designed a smartphone app to help HCPs in selecting ASM selection for patients with seizure onset at age 10 years or above, particularly in settings where no specialized expertise is available [41, 42]. This app is freely available on the Internet (www.epipick.org). In a recent validation study, selection of ASMs recommended by the app based on individual patient characteristics was found to be associated with improved seizure outcomes and fewer adverse effects compared with use of ASMs not recommended by the app [43]. In the future, individualized ASM selection is likely to empowered by more sophisticated technology, including artificial intelligence (machine learning)-based approaches. In a recent study, a machine learning approach combining clinical, genetic and clinical trial data derived from individual patients permitted to construct a computerized model that predicted response to a specific ASM [44].

In addition to facilitating treatment selection, technology will increasingly assist patients and physicians in monitoring response to treatment through a variety of tools, including seizure detection devices [45]. Efforts are also ongoing into development of sophisticated technology, including artificial intelligence, for the prediction of epileptic seizures [46]. This could pave the way to innovative treatment strategies, such as the intermittent 
use of ASMs prior to the time at which a seizure is predicted to occur.

\section{Precision therapies}

In recent years, our understanding of the molecular mechanisms involved in the pathogenesis of epilepsies has improved considerably. One area where advances have been greatest is the genetics of the epilepsies, and in particular the discovery of gene mutations responsible for a large proportion of patients with developmental and epileptic encephalopathies (DEEs) [47]. The elucidation of an epileptogenic mutation permits to establish the functional abnormality responsible for the epilepsy in the affected individual, and to identify (or develop) precision-therapy medications that may be able to correct such abnormality. One example of a precision therapy is the utilization of the ketogenic diet to control seizures associated with Glucose Transporter Type 1 (GLUT1) deficiency syndrome. In this condition, GLUT1 deficiency results in impaired brain uptake of glucose and consequent neuronal dysfunction, which can be overcome by supplying the brain with an alternative source of energy [48]. As discussed in recent reviews [49-51], precision treatments targeting the mechanisms responsible for epilepsy in individuals with specific gene mutations may involve use of drugs previously approved for other indications, a process known as drug repurposing. One example of repurposed drug is the mTOR inhibitor everolimus for the treatment of seizures associated with TSC, as discussed above in this article. Approaches to identify repurposed drugs for specific monogenic epilepsies have been described [52]. In some cases, improved outcomes can be achieved not by administering additional drugs, but by removing medications that can paradoxically aggravate seizures in these patients [49]. Importantly, precision therapies are applicable not only to genetic epilepsies, but also to epilepsies due to other etiologies, such metabolic, inflammatory or immune-mediated causes [53].

At present, application of precision therapies in the management of epilepsy is still in its early days, and will likely expand as further knowledge accrues and newer and more effective targeted treatments are introduced. For genetic epilepsies, targeted (precision) treatments have been reported to improve outcomes in a considerable proportion patients with identified gene mutations [54], although a more recent survey gave a more sober assessment of the current impact of these treatments [55].

\section{Biomarker-guided therapies}

The search for biomarkers continues to be a hot topic in epilepsy research. Biomarkers can be based on a variety of measures such as genetic, molecular, cellular, imaging, and electrophysiological measures, other clinical or laboratory data, or a combination of these $[56,57]$. Biomarkers could potentially be used for different purposes, for example to improve diagnostic accuracy, to identify ongoing epileptogenesis and its mechanisms, to predict seizure response (or lack of response) to specific treatments, to assess the probability of seizure recurrence after treatment withdrawal, or to evaluate susceptibility to adverse drug effects. Some biomarkers, such as the HLA-B*15:02 antigen to identify individuals at high risk of carbamazepine-induced serious cutaneous adverse reactions among Han Chinese and other South Asian ethnic groups, are already in routine clinical use [58].

With respect to potential therapeutic advances, identification and validation of biomarkers could improve treatment outcomes in many ways [56, 57, 59]. First, biomarkers could be used to identify individuals at high risk of developing epilepsy after an epileptogenic insult, thereby permitting selection of these individuals for clinical trials of potential antiepileptogenic therapies. Second, identification of biomarkers predictive of seizure recurrence could facilitate decision on whether to start or withhold ASM therapy in patients who experienced a single seizure. Third, biomarkers predictive of a favorable response to a specific medication would be valuable to select patients to be enrolled in clinical trials of that medication, thereby increasing responder rate and sparing non-responders the burden of receiving placebo or an ineffective treatment. Fourth, biomarkers could theoretically be used to monitor response to treatment, by informing physicians at an early stage on whether the prescribed medication has the required efficacy and safety in a specific individual. Lastly, and most importantly, biomarkers could in the future inform physicians on which ASM is most likely to control seizures effectively and with fewest adverse effects. This may change radically treatment paradigms: for example, the value of a drug which is effective in achieving complete seizure control in $5 \%$ of patients with pharmacoresistant epilepsy would be greatly enhanced if we had a biomarker that can identify beforehand those patients who are responsive to that drug. In that scenario, we would use that drug only in responsive patients, thereby increasing the success rate to $100 \%$.

In practice, in most situations it is unlikely that a single biomarker will provide optimal information for any intended purpose. More realistically, breakthroughs are likely to come from algorithms that utilize a combination of biomarkers and other clinical information. The development of artificial intelligence-based tools can facilitate greatly these approaches [44]. 
Table $3 \mathrm{~A}$ list of investigational drugs currently in clinical development as potential treatments for epilepsy. The list is not exhaustive and does not include medications approved for other indications and currently being tested for potential repurposing in epilepsy

\begin{tabular}{ll}
\hline Anavex 2-73 & Omaveloxolone (RTA 408) \\
Ataluren & OV 329 \\
Carisbamate & Sec-butylpropylacetamide \\
CVL 865 (PF-03672865) & Soticlestat (TAK 935, OV935) \\
CX8998 & Vatiquinone (EPI-743) \\
Ganaxolone & Vixotrigine (CNV 1014802) \\
Huperzyne A & XEN 496 \\
JJ 40411813 & XEN 1101 \\
NBI 921352 (XEN 901) & \\
\hline
\end{tabular}

Novel drugs and the search for disease-modifying therapies The modest impact of second-generation ASMs on seizure outcome in patients resistant to older agents justifies continuing efforts to develop newer and potentially more effective treatments (Table 3). Drug development is currently benefiting from many advances, including deeper knowledge of the mechanisms of epileptogenesis and seizure generation in relation to specific etiologies, improved understanding of mechanisms of pharmacoresistance, and availability of disease-specific models as well as models of pharmacoresistance [53,60]. These advances are changing the paradigms used to discover and develop new drugs.

An important paradigm change is a switch from a focus on medications aimed at suppressing seizures to a focus on treatments targeting the underlying disease, i.e. specific etiologies and the molecular mechanisms associated with such etiologies $[51,61]$. Future precision treatments emerging from this approach will include repurposed drugs [50, 62], novel small molecules, and other treatments based on innovative technologies such as antisense oligonucleotides [63,64] and gene therapy [65]. Some of these therapies require invasive routes of administration, which are also being explored for innovative uses of already established medications [66].

A closely related paradigm change consists in targeting specifically epileptogenesis and other manifestations of the disease $[60,62,67]$. Such treatment could potentially be used to prevent epilepsy, to inhibit its progression (in those syndromes showing a progressive course), or to alter the appearance or progression of comorbidities such as intellectual disability and other disorders. A wide variety of compounds have been found to possess antiepileptogenic and/or neuroprotective activity in preclinical models through antiinflammatory, antioxidant and other mechanisms [68-71]. In addition to novel molecules, these compounds includes naturally occurring substances such as phytocannabinnoids, melatonin, erythropoietin, vitamins and other dietary constituents $[68,70,72-74]$, as well as medications already approved for other indications, such as metformin [75], montelukast [76], atorvastatin, ceftriaxone, and losartan [62]. Whether these properties documented in animal models translate into benefit in the clinical setting remains to be demonstrated. Of note, a number of precision treatments directed at specific etiologies of epilepsy could exhibit diseasemodifying effects, although it is possible that any medication acting on a single molecular pathway may not address all the complex comorbidities associated with aberrant neural networks [61].

As discussed above, clinical trials of investigational new drugs could be facilitated by development of biomarkers to detect the occurrence of epileptogenesis at an early stage, to identify drug responsive patients and to monitor response to treatment. Despite claims to the contrary [77], demonstrating that a chronically administered treatment started before seizure onset prevents the occurrence of seizures in patients still receiving that treatment does not prove epilepsy prevention, because any ASM having a purely symptomatic effect could also produce such an outcome. Likewise, some comorbidities, such as progression of cognitive disability, may be prevented solely as a result of seizure suppression. Truly innovative trial designs will be required to generate unequivocal evidence that a drug is effective in preventing epilepsy, or has a direct disease modifying effect [78].

\section{Conclusions}

Despite the fact that second-generation ASMs have not reduced substantially the burden of pharmacoresistance, advances in the drug treatment of epilepsy continue to be made. These advances result mostly from improved understanding of the comparative efficacy and safety of existing ASMs and from the introduction of newer medicines and innovative formulations. Further advances can be ascribed to technological tools for distant education, telemedicine, and patient empowerment made possible by self-management smartphone-based apps.

It likely that further important therapeutic advances will occur in the coming years. Thanks to ongoing multidisciplinary efforts, clinical outcome for people with epilepsy is likely to improve due to advances in IT technology, development of novel precision therapies, identification of biomarkers to guide drug development as well as routine clinical management, and, ultimately, introduction of truly innovative disease modifying therapies.

\section{Abbreviations}

ASM: Antiseizure medication; DEE: Developmental and epileptic

encephalopathy; CSF: Cerebrospinal fluid; DRESS: Drug Reaction with

Eosinophilia and Systemic Symptoms; DS: Dravet syndrome;

CYP: Cytochrome P450; EEG: Electroencephalography; EURAP: International 
Registry of Antiepileptic Drugs and Pregnancy; FDA: Food and Drug Administration (United States); HCP: Healthcare professional; GABA: Gammaaminobutyric acid; GPR55: G protein-coupled receptor 55; IT: Information technology; LGS: Lennox-Gastaut syndrome; MCM: Major congenital malformation; LOCF: Last-observation-carried-forward; mTOR: Mammalian Target Of Rapamycin; P-gp: P-glycoprotein; SANAD: Standard and New Antiepileptic Drugs; SEGA: Subependymal giant cell astrocytoma; SV2A: Synaptic vesicle 2A; TRPV1: Transient receptor potential vanilloid type 1; TSC: Tuberous sclerosis complex; UGT: Uridine 5'-diphosphoglucuronosyltransferase

\section{Acknowledgments}

Not applicable.

\section{Author's contributions}

The author was solely responsible for the conception and preparation of this article. The author read and approved the final manuscript.

\section{Funding}

This article was not supported by any funding source.

\section{Availability of data and materials}

Not applicable.

\section{Declarations}

Ethics approval and consent to participate Not applicable.

\section{Consent for publication}

The author gave consent for publication of this article.

\section{Competing interests}

The author received speaker's or consultancy fees from Angelini-Arvelle, Biogen, Eisai, GW Pharma, Sanofi, Sun Pharma, UCB Pharma, Xenon Pharma and Zogenix

Received: 28 June 2021 Accepted: 30 July 2021

Published online: 17 September 2021

\section{References}

1. Perucca E. Antiepileptic drugs: evolution of our knowledge and changes in drug trials. Epileptic Disord. 2019;21(4):319-29. https://doi.org/10.1684/epd.2 019.1083.

2. Moshé SL, Perucca E, Ryvlin P, Tomson T. Epilepsy: new advances. Lancet. 2015;385(9971):884-98. https://doi.org/10.1016/S0140-6736(14)60456-6.

3. Perucca E, Brodie MJ, Kwan P, Tomson T. 30 years of second-generation antiseizure medications: impact and future perspectives. Lancet Neurol. 2020;19(6):544-56. https://doi.org/10.1016/S1474-4422(20)30035-1.

4. Dalic L, Cook MJ. Managing drug-resistant epilepsy: challenges and solutions. Neuropsychiatr Dis Treat. 2016;12:2605-16. https://doi.org/10.214 7/NDT.S84852.

5. Perucca P, Scheffer IE, Kiley M. The management of epilepsy in children and adults. Med J Aust. 2018;208(5):226-33. https://doi.org/10.5694/mja17.00951.

6. Perucca $\mathrm{E}$, Tomson T. The pharmacological treatment of epilepsy in adults. Lancet Neurol. 2011;10(5):446-56. https://doi.org/10.1016/S1474-4422(11 )70047-3.

7. Patsalos PN, Berry DJ, Bourgeois BF, Cloyd JC, Glauser TA, Johannessen SI, et al. Antiepileptic drugs--best practice guidelines for therapeutic drug monitoring: a position paper by the subcommission on therapeutic drug monitoring, ILAE Commission on Therapeutic Strategies. Epilepsia. 2008; 49(7):1239-76. https://doi.org/10.1111/j.1528-1167.2008.01561.x.

8. Zaccara G, Perucca E. Interactions between antiepileptic drugs, and between antiepileptic drugs and other drugs. Epileptic Disord. 2014;16(4): 409-31. https://doi.org/10.1684/epd.2014.0714.

9. Schmidt D. Drug treatment strategies for epilepsy revisited: starting early or late? One drug or several drugs? Epileptic Disord. 2016;18(4):356-66. https:// doi.org/10.1684/epd.2016.0882.

10. Lamberink HJ, Otte WM, Geerts AT, Pavlovic M, Ramos-Lizana J, Marson AG, et al. Individualised prediction model of seizure recurrence and long-term outcomes after withdrawal of antiepileptic drugs in seizure-free patients: a systematic review and individual participant data meta-analysis. Lancet Neurol. 2017;16(7):523-31. https://doi.org/10.1016/S1474-4422(17)30114-X.

11. Marson AG, Al-Kharusi AM, Alwaidh M, Appleton R, Baker GA, Chadwick DW, et al. The SANAD study of effectiveness of carbamazepine, gabapentin, lamotrigine, oxcarbazepine, or topiramate for treatment of partial epilepsy: an unblinded randomised controlled trial. Lancet. 2007:369(9566):1000-15. https://doi.org/10.1016/S0140-6736(07)60460-7.

12. Marson AG, Al-Kharusi AM, Alwaidh M, Appleton R, Baker GA, Chadwick DW, et al. The SANAD study of effectiveness of valproate, lamotrigine, or topiramate for generalised and unclassifiable epilepsy: an unblinded randomised controlled trial. Lancet. 2007b;369(9566):1016-26. https://doi. org/10.1016/S0140-6736(07)60461-9.

13. Marson A, Burnside G, Appleton R, Smith D, Leach JP, Sills G, et al. The SANAD II study of the effectiveness and cost-effectiveness of levetiracetam, zonisamide, or lamotrigine for newly diagnosed focal epilepsy: an open-label, non-inferiority, multicentre, phase 4, randomised controlled trial. Lancet. 2021; 397(10282):1363-74. https://doi.org/10.1016/S0140-6736(21)00247-6.

14. Marson A, Burnside G, Appleton R, Smith D, Leach JP, Sills G, et al. The SANAD II study of the effectiveness and cost-effectiveness of valproate versus levetiracetam for newly diagnosed generalised and unclassifiable epilepsy: an open-label, non-inferiority, multicentre, phase 4, randomised controlled trial. Lancet. 2021;397(10282):1375-86. https://doi.org/10.1016/ S0140-6736(21)00246-4.

15. Gesche J, Khanevski M, Solberg C, Beier CP. Resistance to valproic acid as predictor of treatment resistance in genetic generalized epilepsies. Epilepsia. 2017;58(4):e64-9. https://doi.org/10.1111/epi.13702.

16. Meador K. Teratogenicity and antiseizure medications. Epilepsy Curr. 2020; 20(6_suppl):15S-7S

17. Tomson T, Battino D, Perucca E. Teratogenicity of antiepileptic drugs. Curr Opin Neurol. 2019:32(2):246-52. https://doi.org/10.1097/WCO. 0000000000000659 .

18. Tomson T, Battino D, Bonizzoni E, Craig J, Lindhout D, Perucca E, et al. Comparative risk of major congenital malformations with eight different antiepileptic drugs: a prospective cohort study of the EURAP registry. Lancet Neurol. 2018;17(6):530-8. https://doi.org/10.1016/S1474-4422(18)30107-8.

19. Tomson T, Battino D, Bonizzoni E, Craig J, Lindhout D, Perucca E, et al. Declining malformation rates with changed antiepileptic drug prescribing: an observational study. Neurology. 2019;93(9):e831-40. https://doi.org/1 0.1212 WNL.0000000000008001.

20. Steinhoff BJ, Staack AM. Levetiracetam and brivaracetam: a review of evidence from clinical trials and clinical experience. Ther Adv Neurol Disord. 2019;12:1756286419873518.

21. Subramonian A, Farrah K. Brivaracetam versus levetiracetam for epilepsy: a review of comparative clinical safety: Canadian Agency for Drugs and Technologies in Health, Ottawa, Ontario, Canada; 2020. Available at: https:// cadth.ca/sites/default/files/pdf/htis/2020/RC1322\%20Comparing\%202\%20A ntiepileptic\%20Drugs\%20Final.pdf (accessed June 8, 2021)

22. Löscher W, Sills GJ, White HS. The ups and downs of alkyl-carbamates in epilepsy therapy: how does cenobamate differ? Epilepsia. 2021;62(3):596614. https://doi.org/10.1111/epi.16832.

23. Roberti R, De Caro C, lannone LF, Zaccara G, Lattanzi S, Russo E Pharmacology of cenobamate: Mechanism of action, pharmacokinetics, drug-drug interactions and tolerability. CNS Drugs. 2021. https://doi.org/10.1 007/s40263-021-00819-8 (online ahead of print).

24. Krauss GL, Klein P, Brandt C, Lee SK, Milanov I, Milovanovic M, et al. Safety and efficacy of adjunctive cenobamate (YKP3089) in patients with uncontrolled focal seizures: a multicentre, double-blind, randomised, placebo-controlled, dose-response trial. Lancet Neurol. 2020;19(1):38-48. https://doi.org/10.1016/\$1474-4422(19)30399-0.

25. Vossler DG. Remarkably high efficacy of cenobamate in adults with focalonset seizures: a double-blind, randomized, placebo-controlled trial. Epilepsy Curr. 2020;20(2):85-7. https://doi.org/10.1177/1535759720903032.

26. Franco V, Bialer M, Perucca E. Cannabidiol in the treatment of epilepsy: current evidence and perspectives for further research. Neuropharmacology. 2021;185:108442. https://doi.org/10.1016/j.neuropharm.2020.108442.

27. Bialer M, Perucca E. Does cannabidiol have antiseizure activity independent of its interactions with clobazam? An appraisal of the evidence from randomized controlled trials. Epilepsia. 2020;61(6):1082-9. https://doi.org/1 0.1111/epi.16542.

28. Ceulemans B, Schoonjans AS, Marchau F, Paelinck BP, Lagae L. Five-year extended follow-up status of 10 patients with Dravet syndrome treated 
with fenfluramine. Epilepsia. 2016;57(7):e129-34. https://doi.org/10.1111/ epi.13407.

29. Odi R, Invernizzi RW, Gallily T, Bialer M, Perucca E. Fenfluramine repurposing from weight loss to epilepsy: what we do and do not know. Pharmacol Ther. 2021;226:107866. https://doi.org/10.1016/j.pharmthera.2021.107866.

30. Bialer M, Johannessen SI, Koepp MJ, Levy RH, Perucca E, Perucca P, et al. Progress report on new antiepileptic drugs: a summary of the fifteenth Eilat conference on new antiepileptic drugs and devices (EILAT XV). II. Drugs in more advanced clinical development. Epilepsia. 2020;61(11):2365-85. https://doi.org/10.1111/epi.16726.

31. Overwater IE, Rietman AB, van Eeghen AM, de Wit MCY. Everolimus for the treatment of refractory seizures associated with tuberous sclerosis complex (TSC): current perspectives. Ther Clin Risk Manag. 2019;15:951-5. https://doi. org/10.2147/TCRM.S145630.

32. French JA, Lawson JA, Yapici Z, Ikeda H, Polster T, Nabbout R, et al. Adjunctive everolimus therapy for treatment-resistant focal-onset seizures associated with tuberous sclerosis (EXIST-3): a phase 3, randomised, doubleblind, placebo-controlled study. Lancet. 2016;388(10056):2153-63. https:// doi.org/10.1016/S0140-6736(16)31419-2.

33. Fedak Romanowski EM, McNamara NA, Neil EE, Gottlieb-Smith R, Dang LT. Seizure rescue medications for out-of-hospital use in children. J Pediatr. 2021;229:19-25. https://doi.org/10.1016/j.jpeds.2020.10.041.

34. Bouw MR, Chung SS, Gidal B, King A, Tomasovic J, Wheless JW, et al. Clinical pharmacokinetic and pharmacodynamic profile of midazolam nasal spray. Epilepsy Res. 2021;171:106567. https://doi.org/10.1016/j.eplepsyres.2021.1 06567.

35. Boddu SHS, Kumari S. A short review on the intranasal delivery of diazepam for treating acute repetitive seizures. Pharmaceutics. 2020;12(12):1167. https://doi.org/10.3390/pharmaceutics12121167.

36. Gidal B, Klein P, Hirsch L. Seizure clusters, rescue treatments, seizure action plans: unmet needs and emerging formulations. Epilepsy Behav. 2020;112: 107391. https://doi.org/10.1016/j.yebeh.2020.107391.

37. Fesler JR, Stanton S, Merner K, Ross L, McGinley MP, Bena J, et al. Bridging the gap in epilepsy care: a single-center experience of 3700 outpatient teleepilepsy visits. Epilepsia. 2020;61 (8):e95-e100. https:/doi.org/10.1111/epi.16619.

38. Alzamanan MZ, Lim KS, Akmar Ismail M, Abdul GN. Self-management apps for people with epilepsy: systematic analysis. JMIR Mhealth Uhealth. 2021; 9(5):e22489. https://doi.org/10.2196/22489.

39. Patterson V. The development of a smartphone application to help manage epilepsy in resource-limited settings. Seizure. 2020;79:69-74. https://doi. org/10.1016/j.seizure.2020.03.020.

40. Giuliano L, Cicero CE, Trimarchi G, Todaro V, Colli C, Crespo Gómez EB, et al. Usefulness of a smartphone application for the diagnosis of epilepsy: validation study in high-income and rural low-income countries. Epilepsy Behav. 2021;115:107680. https://doi.org/10.1016/j.yebeh.2020.107680.

41. Asadi-Pooya AA, Beniczky S, Rubboli G, Sperling MR, Rampp S, Perucca E. A pragmatic algorithm to select appropriate antiseizure medications in patients with epilepsy. Epilepsia. 2020;61 (8):1668-77. https://doi.org/10.1111/epi.16610

42. Beniczky S, Rampp S, Asadi-Pooya AA, Rubboli G, Perucca E, Sperling MR Optimal choice of antiseizure medication: agreement among experts and validation of a web-based decision support application. Epilepsia. 2021;62(1): 220-7. https://doi.org/10.1111/epi.16763.

43. Hadady L, Klivényi P, Asadi-Pooya AA, Rampp S, Fabó D, Bereczki C, et al. Web-based decision support system for patient-tailored selection of antiseizure treatment medication in adolescents and adults: An external validation study. 2021 (submitted).

44. de Jong J, Cutcutache I, Page M, Emmoufti S, Dilley C, Fröhlich H, et al. Towards realizing the vision of precision medicine: Al based prediction of clinical drug response. Brain. 2021:awab108. https//doi.org/10.1093/brain/awab108 Online ahead of print.

45. Beniczky S, Wiebe S, Jeppesen J, Tatum WO, Brazdil M, Wang Y, et al. Automated seizure detection using wearable devices: a clinical practice guideline of the international league against epilepsy and the International Federation of Clinical Neurophysiology. Epilepsia. 2021;62(3):632-46. https:// doi.org/10.1111/epi.16818.

46. Rasheed K, Qayyum A, Qadir J, Sivathamboo S, Kwan P, Kuhlmann L, et al. Machine learning for predicting epileptic seizures using EEG signals: a review. IEEE Rev Biomed Eng. 2021;14:139-55. https://doi.org/10.1109/ RBME.2020.3008792.

47. Perucca P, Bahlo M, Berkovic SF. The genetics of epilepsy. Annu Rev Genomics Hum Genet. 2020;21(1):205-30. https://doi.org/10.1146/annurevgenom-120219-074937.
48. Daci A, Bozalija A, Jashari F, Krasniqi S. Individualizing treatment approaches for epileptic patients with glucose transporter Type1 (GLUT-1) deficiency. Int J Mol Sci. 2018;19(1):122. https://doi.org/10.3390/ijms19010122.

49. Perucca P, Perucca E. Identifying mutations in epilepsy genes: impact on treatment selection. Epilepsy Res. 2019;152:18-30. https://doi.org/10.1016/j. eplepsyres.2019.03.001

50. Specchio N, Pietrafusa N, Perucca E, Cross JH. New paradigms for the treatment of pediatric monogenic epilepsies: progressing toward precision medicine. Epilepsy Behav. 2021:107961. https://doi.org/10.1016/j.yebeh.2 021.107961 Online ahead of print.

51. Byrne S, Enright N, Delanty N. Precision therapy in the genetic epilepsies of childhood. Dev Med Child Neurol. 2021. https://doi.org/10.1111/dmcn.14929 Online ahead of print

52. Atkin TA, Maher CM, Gerlach AC, Gay BC, Antonio BM, Santos SC, et al. A comprehensive approach to identifying repurposed drugs to treat SCN8A epilepsy. Epilepsia. 2018;59(4):802-13. https://doi.org/10.1111/epi.14037.

53. Löscher W, Potschka H, Sisodiya SM, Vezzani A. Drug resistance in epilepsy: clinical impact, potential mechanisms, and new innovative treatment options. Pharmacol Rev. 2020;72(3):606-38. https://doi.org/1 0.1124/pr.120.019539.

54. Peng J, Pang N, Wang Y, Wang X-L, Chen J, Xiong J. Next-generation sequencing improves treatment efficacy and reduces hospitalization in children with drug-resistant epilepsy. CNS Neurosci Ther. 2019;25(1):14-20. https://doi.org/10.1111/cns.12869.

55. Balestrini S, Chiarello D, Gogou M, Silvennoinen K, Puvirajasinghe C, Jones WD, et al. Real-life survey of pitfalls and successes of precision medicine in genetic epilepsies. J Neurol Neurosurg Psychiatry. 2021:jnnp-2020-325932. https://doi.org/10.1136/jnnp-2020-325932 Online ahead of print.

56. Kobylarek D, Iwanowski P, Lewandowska Z, Limphaibool N, Szafranek S, Labrzycka A, et al. Advances in the potential biomarkers of epilepsy. Front Neurol. 2019;10:685. https://doi.org/10.3389/fneur.2019.00685.

57. Engel J Jr, Pitkänen A. Biomarkers for epileptogenesis and its treatment. Neuropharmacology. 2020;167:107735. https://doi.org/10.1016/j.neuropha rm.2019.107735.

58. Chang $\mathrm{CJ}$, Chen CB, Hung SI, Ji C, Chung WH. Pharmacogenetic testing for prevention of severe cutaneous adverse drug reactions. Front Pharmacol. 2020;11:969. https://doi.org/10.3389/fphar.2020.00969.

59. Simonato M, Agoston DV, Brooks-Kayal A, Dulla C, Fureman B, Henshall DC, et al. Identification of clinically relevant biomarkers of epileptogenesis - a strategic roadmap. Nat Rev Neurol. 2021;17(4):231-42. https://doi.org/10.103 8/s41582-021-00461-4

60. Galanopoulou AS, Löscher W, Lubbers L, O'Brien TJ, Staley K, Vezzani A, et al. Antiepileptogenesis and disease modification: Progress, challenges, and the path forward-report of the preclinical working group of the 2018 NINDS-sponsored antiepileptogenesis and disease modification workshop. Epilepsia Open. 2021;6(2):276-96. https://doi.org/10.1002/epi4.12490.

61. Kearney H, Byrne S, Cavalleri GL, Delanty N. Tackling epilepsy with highdefinition precision medicine: a review. JAMA Neurol. 2019;76(9):1109-16. https://doi.org/10.1001/jamaneurol.2019.2384.

62. Klein P, Friedman A, Hameed MQ, Kaminski RM, Bar-Klein G, Klitgaard H, et al. Repurposed molecules for antiepileptogenesis: missing an opportunity to prevent epilepsy? Epilepsia. 2020;61(3):359-86. https://doi.org/10.1111/ epi.16450.

63. Han Z, Chen C, Christiansen A, Ji S, Lin Q, Anumonwo C, et al. Antisense oligonucleotides increase Scnla expression and reduce seizures and SUDEP incidence in a mouse model of Dravet syndrome. Sci Transl Med. 2020; 12(558):eaaz6100.

64. Ahonen S, Nitschke S, Grossman TR, Kordasiewicz H, Wang P, Zhao X, et al. Gys 1 antisense therapy rescues neuropathological bases of murine Lafora disease. Brain. 2021:awab194. https://doi.org/10.1093/brain/awab194 Online ahead of print.

65. Higurashi N, Broccoli V, Hirose S. Genetics and gene therapy in Dravet syndrome. Epilepsy Behav. 2021:108043. https://doi.org/10.1016/j.yebeh.2 021.108043 Online ahead of print.

66. Cook M, Murphy M, Bulluss K, D'Souza W, Plummer C, Priest E, et al. Antiseizure therapy with a long-term, implanted intra-cerebroventricular delivery system for drug-resistant epilepsy: a first-in-man study. EClinicalMedicine. 2020;22:100326. https://doi.org/10.1016/j.eclinm.2020.100326.

67. Löscher W. The holy grail of epilepsy prevention: preclinical approaches to antiepileptogenic treatments. Neuropharmacology. 2020;167:107605. https:// doi.org/10.1016/j.neuropharm.2019.04.011. 
68. Rahman MH, Akter R, Kamal MA. Prospective function of different antioxidant containing natural products in the treatment of neurodegenerative disease. CNS Neurol Disord drug targets 2020 Jul 22. Doi: https://doi.org/10.2174/1871 527319666200722153611. Online ahead of print.

69. Leavy A, Jimenez Mateos EM. Perinatal brain injury and inflammation: lessons from experimental murine models. Cells. 2020;9(12):2640. https://doi. org/10.3390/cells9122640.

70. Yang N, Guan QW, Chen FH, Xia QX, Yin XX, Zhou HH, et al. Antioxidants targeting mitochondrial oxidative stress: promising neuroprotectants for epilepsy. Oxidative Med Cell Longev. 2020:6687185. https://doi.org/10.11 $55 / 2020 / 6687185$

71. Zavala-Tecuapetla C, Cuellar-Herrera M, Luna-Munguia H. Insights into potential targets for therapeutic intervention in epilepsy. Int J Mol Sci. 2020; 21(22):8573. https://doi.org/10.3390/ijms21228573.

72. Frajewicki A, Laštůvka Z, Borbélyová V, Khan S, Jandová K, Janišová K, et al. Perinatal hypoxic-ischemic damage: review of the current treatment possibilities. Physiol Res. 2020;69(Suppl 3):S379-401. https://doi.org/10.3354 9/physiolres.934595.

73. Murugan M, Boison D. Ketogenic diet, neuroprotection, and antiepileptogenesis. Epilepsy Res. 2020;167:106444. https://doi.org/10.1016/j. eplepsyres.2020.106444.

74. Stone NL, Murphy AJ, England TJ, O'Sullivan SE. A systematic review of minor phytocannabinoids with promising neuroprotective potential. Br J Pharmacol. 2020;177(19):4330-52. https://doi.org/10.1111/bph.15185.

75. Sanz P, Serratosa JM, Sánchez MP. Beneficial effects of metformin on the central nervous system, with a focus on epilepsy and Lafora disease. Int J Mol Sci. 2021;22(10):5351. https://doi.org/10.3390/ijms22105351.

76. Tesfaye BA, Hailu HG, Zewdie KA, Ayza MA, Berhe DF. Montelukast: the new therapeutic option for the treatment of epilepsy. J Exp Pharmacol. 2021;13 23-31. https://doi.org/10.2147/JEP.S277720.

77. Kotulska K, Kwiatkowski DJ, Curatolo P, Weschke B, Riney K, Jansen F, et al. Prevention of epilepsy in infants with tuberous sclerosis complex in the EPISTOP trial. Ann Neurol. 2021;89(2):304-14. https://doi.org/10.1002/ana.2 5956.

78. Franco V, French JA, Perucca E. Challenges in the clinical development of new antiepileptic drugs. Pharmacol Res. 2016;103:95-104. https://doi.org/1 0.1016/.jphrs.2015.11.007

Ready to submit your research? Choose BMC and benefit from:

- fast, convenient online submission

- thorough peer review by experienced researchers in your field

- rapid publication on acceptance

- support for research data, including large and complex data types

- gold Open Access which fosters wider collaboration and increased citations

- maximum visibility for your research: over $100 \mathrm{M}$ website views per year

At $\mathrm{BMC}$, research is always in progress.

Learn more biomedcentral.com/submissions 